\title{
PPAT Gene
}

National Cancer Institute

\section{Source}

National Cancer Institute. PPAT Gene. NCI Thesaurus. Code C45563.

This gene plays a role in de novo purine nucleotide biosynthesis. 